\title{
E-tiviteter som eksamensform
}

\section{Anette Grønning}

Adjunkt, ph.d.

Kort beskrivelse af aktuel beskæftigelse.

\section{Abstract (danish)}

Med udgangspunkt i faget "Digital kommunikation på arbejde" prcesenterer og diskuterer denne artikel en rcekke anvendte digitale eksamensformer (e-tiviteter).

E-tiviteterne er udarbejdet med støtte i Gilly Salmons 5-trins-model og etivitet-koncept. Den anvendte e-leringsplatform er Blackboard, som de studerende og underviseren kender i forvejen. I artiklen prcesenteres fagets e-tiviteter og undervisningsforløbet med e-tiviteter som eksamensform diskuteres. En rcekke fordele og ulemper ved at veksle mellem offline- og online-aktitiveter (blended learning) bliver behandlet. Det konkluderes, at de studerendes engagement og motivation kan øges ved at koble 
e-tiviteter sammen med eksamensformen "80\% tilstedevcrelse og aktiv deltagelse". Desuden fremhreves det, at aktivitetsniveauet mellem lektionerne og forberedelsesomfanget øges, ligesom de studerende forsøges motiveret til higher order thinking ved fx i højere og mere synlig grad at blive opfordret til at tage ansvar for egen laring, udføre analyse og indgå i processen med kritisk refleksion. Endelig muliggør onlineforløbet, at hele processen dokumenteres undervejs i faget til gavn for både underviser og studerende.

\section{Abstract (english)}

E-tivities as method of assessment

Based on the course "Digital communication in action", this article presents and discusses a number of digital methods of assessment ( $e$ tivities). The e-tivities are developed with an eye to Gilly Salmon's 5stage model and e-tivity concept. A number of advantages and disadvantages by switching between offline and online activities (blended learning) are examined. It is concluded that the students' involvement and motivation can be increased by linking e-tivities to the method of assessment "80\% presence and active participation". Furthermore, it is emphasised that the level of activity between the lessons and the extent of preparation increase,and the students are sought motivated to higher order thinking e.g. by increasingly taking responsibility for own learning, completing analysis and participating in the process with critical reflection. Finally, the online part enables that the entire process is documented during the course of benefit to both the teacher and the students.

\section{Indledning}

Med udgangspunkt i faget "Digital kommunikation på arbejde" udviklet af skribenten ved Medievidenskab, Syddansk Universitet præsenterer og diskuterer denne artikel en række anvendte digitale eksamensformer (etiviteter). E-tiviteterne er udarbejdet med støtte i Gilly Salmons 5-trinsmodel og e-tivitet-koncept. "Digital Kommunikation på arbejde" er et tilvalgsfag for 3. og 5. semester-studerende på BA-niveau (10 ECTS). Faget introducerer de studerende til forskning i computermedieret kommunikation og har været udbudt 3 gange, senest i efteråret 2010 med deltagelse af 72 studerende. Den anvendte e-læringsplatform er Blackboard, som de studerende og underviseren kender i forvejen. Faget omfatter formelt $10 \times 3$ lektioner vekslende mellem offline- og onlineundervisning (blended learning), sidstnævnte via software-programmet Adobe Connect. Fagets eksamensbetingelser er ifølge Studieordningen "Hjemmeopgave uden mundtligt forsvar eller Undervisningsdeltagelse." For at bestå faget skal den studerende i løbet af semestret deltage aktivt i undervisningen og interaktivt i e-tivitetsforløbet indeholdende et diskussionsforum, en blog og en wiki, som alle er oprettet i Blackboard. Desuden skal den studerende have deltaget aktivt i et særligt online 
gruppeforløb med minimum et mundtligt oplæg og sammenlagt demonstrere en tilstedeværelsesprocent på mindst $80 \%$.

I artiklen præsenteres dels faget og fagets e-tiviteter, ligesom undervisningsforløbet med e-tiviteternes indhold og fagets eksamensform diskuteres. En række fordele og ulemper ved at veksle mellem offline- og online-aktitiveter (blended learning) bliver behandlet. Artiklen er udarbejdet på baggrund af underviserens erfaring med faget og de studerendes evaluering af hver enkelt e-tivitet samt af faget generelt.

Brugen af informations- og kommunikationsteknologi har helt overordnet $\mathrm{i}$ mange kontekster afstedkommet nye tanker om, hvordan vi kan gennemføre undervisning online (Monty \& Olsen, 2006). I den bedste af alle verdener bør eksamensform og undervisningsformer altid være afstemt i forhold til hinanden, jf. begrebet constructive alignment (Biggs \& Tang, 2009). Ofte er studieordninger dog vanskelige at ændre fra semester til semester, ligesom der i nogle uddannelser (fx på Syddansk Universitet) er krav om, at den studerende ved færdiggørelse af sin uddannelse skal være udprøvet i samtlige af studiets mulige eksamensformer (som fx mundtlig, skriftlig, tilstedeværelse). Den studerende vælger typisk de respektive valgfag som led i at justere dette. I dette tilfælde var eksamensformen afgørende for ønsket om at tænke nyt i forhold til undervisningsformerne. Ligeledes afstedkom behovet for at øge de studerendes engagement i undervisningen (fysisk tilstedeværelse er ikke ensbetydende med fagligt aktiv tilstedeværelse, end ikke på et universitet) samt ønsket om at videreudvikle de studerendes digitale kompetencer overvejelser om nye eksamensformer. I det beskrevne tilfælde var det for det første hensigtsmæssigt at øge aktiviteten mellem lektionerne og forberedelsesomfanget generelt, da tidligere erfaringer på faget havde vist, at en stor del af de studerende mødte op uden forberedelse - ligesom andre studier (fx Monty \& Olsen, 2006) har kunnet berette om. For det andet var det tankevækkende, at så mange af de studerende kun overfladisk havde kendskab til blogs, wikier og andre digitale ressourcer. Ved hjælp af en spørgeskemaundersøgelse i forbindelse med fagets begyndelse kom det eksempelvis frem, at kun 13\% af de studerende dagligt læser blogs (39\% af de studerende læser blogs indimellem). Til gengæld rapporterede de studerende, at de så godt som alle er aktive på Facebook med egen profil, ligesom de fleste studerende svarede, at de dagligt chatter fx via msn eller Facebook. I den anvendte case blev ambitionen at udvikle, afprøve og dokumentere et undervisningsforløb, hvor der blev skruet kraftigt op for det digitale arbejde uden at slække på fagligheden. Som underviser har skribenten tidligere oplevet, at både de studerende og underviseren bliver så optaget af de nye digitale muligheder, at det kernefaglige falder for meget i baggrunden. Indførelse af obligatoriske online opgaver måtte altså ikke ødelægge sammenhængen og det faglige niveau, men skulle derimod helst styrke læringsprocessen. Ved at introducere e-tiviteter som eksamensform og krav om digital deltagelse kunne eksamensformen "Undervisningsdeltagelse" yderligere vise sig at få en helt ny betydning for faget. Inddragelsen af Gilmons 5-trins model var ikke åbenlys fra begyndelsen, da underviseren ikke tidligere har arbejdet med denne, men ønsket om læringsmæssigt at sikre en stilladsering fik underviseren til at udarbejde e-tiviteterne med støtte i modellen. 
Faget

"Digital kommunikation på arbejde" er et tilvalgsfag for 3. og 5. semesterstuderende på BA-niveau (10 ECTS). Faget udbydes af Medievidenskab, Institut for Litteratur, Kultur og Medier, men er åbent for alle BAstuderende ved det Humanistiske Fakultet, Syddansk Universitet. Pensum introducerer de studerende til forskning i computermedieret kommunikation, herunder computermedieret diskursanalyse, kernebegreber som interaktivitet og social presence med særligt fokus på, hvorledes blogs, e-mail, sms og chat bruges i det professionelle liv mellem på den ene side kunder, borgere, patienter, klienter og på den anden side medarbejdere og personale på offentlige og private arbejdspladser. Faget har været udbudt 3 gange, senest efteråret 2010 med deltagelse af 72 studerende. De studerende kommer fortrinsvis fra Medievidenskab, International Virksomhedskommunikation og Dansk/Nordisk. Semestret omfatter formelt $10 \times 3$ lektioner à 45 minutter, som underviseren har mulighed for at sammensætte på forskellig vis. Ambitionen blev at veksle mellem offline- og online-undervisning (blended learning), sidstnævnte via Adobe Connect. Den anvendte e-læringsplatform er Blackboard, som de studerende og underviseren kender i forvejen.

\section{E-titivitetsbegrebet}

I mere end 10 år har Gilly Salmon skrevet om begreberne e-moderating og e-tivitet. Salmon bruger begrebet e-tivitet som en ramme for aktiv og interaktiv online læring. Mere specifikt er begrebet dækkende for en online aktivitet, som involverer minimum to mennesker (sædvanligvis mange flere), der på en eller anden måde arbejder sammen (Salmon, 2002, s. 2). Salmon understreger, at e-tiviteter kan bruges på mange forskellige måder, men at de alle har nogle fælles træk. E-tiviteter er motiverende, engagerende og har et formål. De er baseret på interaktion mellem deltagerne, fortrinsvis skriftlig. De er udviklet og styret af en e-moderator. De er asynkrone og gennemføres over tid. Kernen i en e-tivitet er aktiv læring i grupper, men mønstret og processen er anderledes end ved interaktion i et undervisningslokale. Deltagerne i en e-tivitet er ikke afhængige af at være fysisk til stede samtidig, hvilket fordrer en fleksibel arbejdsform. Underviseren får først og fremmest rollen som e-moderator, og e-tiviteten kræver, at alle studerende bliver deltagende. En e-tivitet er desuden kendetegnet ved at være billig at udvikle og gennemføre.

Derudover er de væsentligste træk, at deltagerne skal lægge indhold ud på nettet, og at e-tiviteten også indeholder et processuelt interaktivt eller deltagende element i form af krav om deltagerfeedback.

E-moderatoren (underviseren) har til opgave at hjælpe til en god måde at kommunikere online på og foregå som eksempel for deltagerne. Desuden skal e-moderatoren bidrage med feedback i form af fx opsummering og/eller kritik (Salmon 2002, s. I).

Bag begrebet e-tivitet findes en række underliggende begreber, som Salmon trækker på. Salmon fremhæver selv begreber som videncirkulation, situeret læring, dybde- og overfladelæring, refleksion samt teori om engagement (Salmon, 2002, s. 208-211). 
I forbindelse med e-tivitetsbegrebet anvender Gilly Salmon sammen med David Jacques en 5-trins-model "The five-stage framework" (Jacques \& Salmon, 2007, s. 43), der fungerer som en form for scaffolding eller stilladsering, dvs. at hvert trin støtter op om og bygger videre på deltagernes ekspertise. Modellen er indgående beskrevet i en række danske forskningsartikler, eksempelvis i Monty \& Olsen (2006), hvor også KVLs mangeårige indsats på netop dette felt er detaljeret beskrevet. En mere diskuterende gennemgang af Salmons arbejde omfattende e-tiviteter og 5 -trins-modellen findes hos Slevin (2006), som ydermere rejser 3 kritikpunkter til videre diskussion. Endelig henvises til Salmon (2002) og Jacques \& Salmon (2007) for yderligere indføring.

Her følger udelukkende en kort introduktion af 5-trins-modellen:

Salmons 5-trins-model er en undervisningsmodel, der lægger vægt på via e-tiviteter at fremme interaktion mellem deltagerne i læreprocessen og tager højde for, at der er forskel på mundtlige og skriftlige kommunikationsformer. Det væsentlige er, at de studerende skal lære at skabe og indgå i et fælles online miljø, hvor de gennem e-tiviteter lærer at tilbyde egen viden til andre og skabe viden sammen med andre.

Trin 1 (Access and motivation) har fokus på adgang og motivation. Dette trin handler først og fremmest om at få online systemet til at virke, få adgang dertil og byde hinanden indenfor via velkomst og opmuntring. Trin 2 (Online Socialization) ansporer særligt til online socialisering. Her vænner deltagerne sig til at bidrage og indgå i andres indlæg med kommentarer. Dette forudsætter brobygning mellem den kulturelle, sociale og læringsmæssige kontekst. Trin 3 (Information exchange) indeholder informationsudveksling på et højere niveau. Her skal deltagerne fx finde ressourcer i læringsmaterialet og forholde sig individuelt og kritisk til disse. Trin 4 (Knowledge construction) kræver videnskonstruktion og er samtidig meget procesorienteret. Trin 5 (Development) fokuserer på udvikling, hvor support og feedback bliver altafgørende. E-tiviteterne, som er udarbejdet til faget "Digital kommunikation på arbejde" og som gennemgås i denne artikel, er alle udviklet med støtte i denne 5-trinsmodel.

Gilly Salmon har for nyligt på en præsentation ved den europæiske online konference EDEN 2011 foretaget ændringer i begreberne, der omhandler de fem trin i modellen. Disse nye betegnelser er ikke indarbejdet her, men kan findes i Salmons præsentation via www.slideshare.net.

I Danmark har bl.a. Nina Bonderup Dohn og Lars Johnsen (2009) beskæftiget sig med e-læring baseret på web 2.0 ressourcer. Til brug for udvikling af det beskrevne læringsforløb er inspiration fra deres bog særligt hentet i del 2 omhandlende blogs og wikier som læringsredskaber. Bogen giver en række eksempler på fokuspunkter for didaktisk planlægning og konkrete eksempler på blog og wikier som læringsredskaber.

Som det fremgår af nedenstående semesterplan (grafik 1), blev undervisningsforløbet gennemført som blended learning, dvs. i et online og offline forløb med 10 undervisningsgange på universitetet og 3 online undervisningsgange, hvor de studerende selv måtte bestemme, hvor de 
ville være, blot de befandt sig tæt ved en computer med internetadgang. Helt fra fagets start blev headset og kamera skrevet ind på pensumlisten som en selvfølgelighed på linje med det øvrige materiale (bøger, kompendium), der skulle anskaffes for at følge forløbet. De enkelte etiviteter var ligeledes fra begyndelsen af semestret synlige på semesterplanen, så de studerende hurtigt kunne danne sig et overblik over processen og det obligatoriske online arbejde, der fulgte med undervejs mellem fagets lektioner.

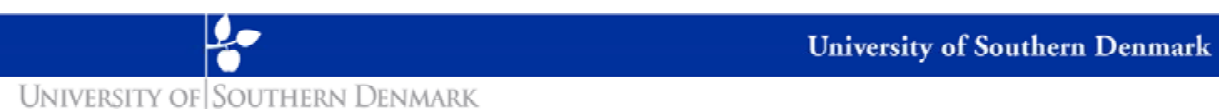

\section{Blended learning semesterplan}

\begin{tabular}{|l|l|l|l|}
\hline Uge & Offline lektioner & Online lektioner (E-tivity 3) & E-tivity 1, 2 \& 4 \\
\hline $\mathbf{1}$ & $3 \times 45$ minutter & & E-tivity 1: Vores Cafe \\
\hline $\mathbf{2}$ & $3 \times 45$ minutter & & E-tivity 1: Vores Cafe \\
\hline $\mathbf{3}$ & $3 \times 45$ minutter & & E-tivity 1: Vores Cafe \\
\hline $\mathbf{4}$ & & E-tivity 3: Intro til Adobe Connect & E-tivity 2: Vores Blog \\
\hline $\mathbf{5}$ & $3 \times 45$ minutter & & E-tivity 2: Vores Blog \\
\hline $\mathbf{6}$ & $3 \times 45$ minutter & & E-tivity 2: Vores Blog \\
\hline $\mathbf{7}$ & & E-tivity 3: Virtuelle fremlæggelser & E-tivity 2: Vores Blog \\
\hline $\mathbf{8}$ & & E-tivity 3: Virtuelle fremlæggelser & E-tivity 2: Vores Blog \\
\hline $\mathbf{9}$ & $3 \times 45$ minutter & & E-tivity 2: Vores Blog \\
\hline $\mathbf{1 0}$ & $3 \times 45$ minutter & & E-tivity 4: Vores Wiki \\
\hline $\mathbf{1 1}$ & $3 \times 45$ minutter & & E-tivity 4: Vores Wiki \\
\hline $\mathbf{1 2}$ & $3 \times 45$ minutter & & E-tivity 4: Vores Wiki \\
\hline $\mathbf{1 3}$ & $3 \times 45$ minutter & & E-tivity 4: Vores Wiki \\
\hline
\end{tabular}

Figur 1. Oversigt over det samlede undervisningsforløb.

Fagets eksamensbetingelser er ifølge Studieordningen: "Hjemmeopgave uden mundtligt forsvar eller Undervisningsdeltagelse." For at bestå faget skal den studerende i løbet af semestret deltage aktivt i undervisningen og interaktivt i et e-tivitetsforløb indeholdende diskussionsforum, en blog og en wiki, som er oprettet i Blackboard. Desuden skal den studerende have deltaget aktivt i et særligt online gruppeforløb med minimum et mundtligt oplæg og demonstrere en tilstedeværelsesprocent på mindst 80\%.

\section{E-tiviteterne}

Faget omfatter følgende e-tiviteter: Vores cafe (e-tivitet 1 ), Vores blog (etivitet 2), Virtuel fremlæggelse (e-tivitet 3) og Vores wiki (e-tivitet 4). Etivitet 1, 2 og 4 gennemføres via Blackboard og er asynkrone, e-tivitet 3 gennemføres via Adobe Connect og er synkron. Her følger en kort gennemgang af hver e-tivitet.

\section{E-tivitet 1 - Vores cafe}

Ressourcen er diskussionsforummet til "Digital kommunikation på arbejde" via e-learn.sdu.dk. Formålet er at mødes virtuelt og skabe virtuel 
aktivitet. Den studerende skal poste en besked, hvor han/hun fortæller lidt om sine interesser. Beskeden kan ses af alle studerende på holdet.

Beskeden skal være kort, ikke mere indhold end på et postkort. Den studerende opfordres til at skrive noget om sit favoritfag, sin yndlingsbeskæftigelse eller om noget, han/hun lige har opdaget på internettet. Der må gerne indsættes et eller flere billeder, men det er ikke et krav. I stedet for tekst, eller som supplement til tekst/billede, kan den studerende også vælge at optage en lydfil (fx i Audacity), hvor den studerende fortæller det, han/hun har på hjerte. Den studerende bliver bedt om at returnere til diskussionsforummet fra tid til anden og svare på/føje noget til minimum 3 medstuderendes indlæg. E-tivitet 1 løber henover en periode på 3 uger, og den studerende skal poste det første indlæg inden for den første uge.

E-tivitet 1 implicerer særligt trin 1 og 2 i Salmons model.

Der blev postet 351 forskellige bidrag, svar og kommentarer i e-tivitet 1 . Underviseren lagde ud med en tekst, et foto og en lydfil. Flere af de studerende bidrog med fotos som supplement til deres tekst. En enkelt studerende havde helt udeladt tekst og udelukkende benyttet sig af lyd, udarbejdet i Audacity. De studerende med visuelt og lydligt materiale fik særlig megen respons fra deres medstuderende. Flere studerende fandt ud af, at de havde fælles interesser både i universitetsmiljøet ( $\mathrm{fx}$ teoretikeren Luhmann) og uden for universitetsmiljøet (fx håndbold som aktive idrætsfolk). Selvom e-tiviteten fortrinsvis var en (social) opvarmning til de efterfølgende e-tiviteter, begyndte det faglige fællesskab implicit at spille en rolle for nogen.

\section{E-tivitet 2 - Vores blog}

Ressourcen er blogmodulet til "Digital kommunikation på arbejde" via elearn.sdu.dk. Formålet er at skabe en samling af brugbare kilder (og vinkler) om emnet digital kommunikation i en organisatorisk kontekst. Den studerende skal i forbindelse med e-tivitet 2 finde en kilde og poste url'en sammen med en tekst, hvor han/hun svarer på følgende: Hvorfor vil en studerende have glæde af at gå til, læse eller bruge den vinkel, du har angivet? Hvad er det interessante? Angiv din mening om kildens kvalitet og validitet, $\mathrm{fx}$ ved at kommentere kildens oprindelsesdato, autoritet, anvendelighed for dig eller brug andre relevante evalueringsmåder. Derudover skal den studerende vælge mindst et af sine medstuderendes indlæg og i en kommentar give sin mening til kende om vinklen/kilden. Endelig skal den studerende via kommentarfeltet som ophavskvinde/mand forholde sig til de kommentarer, han/hun selv måtte fă. E-tivitet 2 løber henover en periode på fem uger, og den studerende skal poste det første indlæg inden for de første to uger.

E-tivitet 2 implicerer særligt trin 3 i Salmons model.

Der blev postet 74 blogindlæg og 237 kommentarer i e-tivitet 2 . Underviseren lagde ud med et blogindlæg om forskning i computermedieret kommunikation. De studerende valgte en række forskellige vinkler, som efterfølgende temamæssigt blev sorteret af underviseren. Disse temaer blev styrende for e-tivitet 4 senere i semestret. Langt de fleste studerende havde svært ved at validere deres kilde(r). 
Bevidstheden om at angive sin mening om kildens kvalitet og validitet, $\mathrm{fx}$ ved at kommentere kildens oprindelsesdato, autoritet, anvendelighed osv. var så godt som ikke-eksisterende. Her måtte en særlig runde til for at få dette på plads. Væsentligt er det her at fremhæve, at underviseren som emoderator langt hurtigere (om overhovedet) end offline opdager behovet for en sådan justering. Desuden var sammenhængen mellem de forskellige blogindlæg af meget forskelligartet kvalitet. Flere studerende bloggede simpelthen om de samme vinkler uden at opdage hinanden før sidst i processen eller efter at være blevet gjort opmærksom på det. Her lærte underviseren, at en øget sammenhængskraft $\mathrm{i}$ et fremtidigt forløb fordrer, at man (endnu mere) eksplicit skal kræve, at den studerende læser samtlige publicerede blogindlæg, før han/hun lægger sit eget blogindlæg og eventuelle kommentarer ud. Dette er egentlig også i tråd med Salmons anbefalinger, men alligevel vanskeligt i praksis at styre for en travl emoderator uden erfaring i 5-trins-modellen - og med travle studerende, der ønsker at vinge "e-tivitet 2" af på to do-listen.

\section{E-tivitet 3 - Virtuel fremlæeggelse}

Forud for denne e-tivitet var de studerende blevet introduceret til programmet Adobe Connect. Her blev holdet delt i to og fik en fælles introduktion af software programmet. Introduktionen blev givet af ansatte ved e-læringsenheden på universitetet, som gennem hele forløbet har været en betydelig støtte for underviseren. Ressourcen for e-tiviteten er et mødelink, som de studerende selv har oprettet. Formålet med e-tiviteten er at blive fortrolig med online møder, fremlæggelse af budskaber/dokumenter og efterlevelse af online husregler, sidstnævnte vender jeg tilbage til. De studerende var delt i 14 grupper à 5 studerende, enkelte grupper med 6 studerende. Hvert gruppemedlem fremlagde ca. 10 minutter på baggrund af forberedt materiale (inkl. mindst et dokument). Mens gruppemedlemmet fremlagde (a), indtog de øvrige gruppemedlemmer andre roller: ansvarlig for at oprette møderum + optagelse af mødet (b), mødeleder (c), præsentation af oplægsholder (d) og opponent $(\mathrm{e})$. Hver rolle var på forhånd detaljeret beskrevet på skrift for de studerende, og tidsmæssigt var der ligeledes klare krav for oplæg og efterfølgende drøftelse. E-tivitet 3 er således den eneste synkrone e-tivitet i dette forløb. Her afviger e-tiviteten lidt fra Salmons e-tiviteter, som alle er synkrone.

Udover selve introduktionen til Adobe Connect er der afsat to uger til at nå dette gruppearbejde. Undervejs kommer underviseren og to moderatorer (studerende fra faget, året før) på virtuelt besøg. De studerende holder løbende underviseren orienteret (via e-mail) om deres gruppearbejde. Efter de virtuelle fremlæggelser skal de studerende medbringe optagelserne af fremlæggelserne til den efterfølgende offline undervisning, hvor de studerende i fællesskab i grupperne på baggrund af en række diskussionsspørgsmål skal reflektere over det, der er foregået i online gruppearbejdet. Underviseren giver også her feedback på baggrund af noterne fra besøgene under gruppearbejdet og optagelserne. Endelig foretages der gruppevis en skriftlig evaluering af e-tivitet 3.

E-tivitet 3 implicerer særligt trin 4 og 5 i Salmons model. 


\section{Online husregler}

I forbindelse med e-tivitet 3 og formålet med denne nævnes de såkaldte online husregler. Det har vist sig formålstjenligt at eksplicitere et sæt af enkle regler og opfordringer inden det virtuelle gruppearbejde i Adobe Connect. Over for de studerende beskrives husreglerne således: "At deltage $i$ et online-møde i en stor eller mindre gruppe i en undervisningssituation kræver disciplin og tålmodighed. Husreglerne er blevet til på baggrund af sidste års erfaringer fra dette fag. Du bedes læse og efterleve disse husregler for at sikre det optimale udbytte af møderne for både dig selv og de øvrige deltagere". Herefter fremhæves særligt seks områder med en række gode råd og anvisninger. De seks områder er: "Vær velforberedt og koncentreret", "Chat - hvad er god stil", "Humørikoner", "Gruppesamarbejde", "Spild ikke dine medstuderendes tid" og "Afsæt god tid". Områderne kan virke indlysende, men at udstikke retningslinjer har vist sig hensigtsmæssigt for online undervisningen, således at de studerende forholder sig til disse udvalgte områder inden de virtuelle præsentationer. Særligt chatmodulet blev brugt og misbrugt på forskellig vis, inden husreglerne blev indført, ligesom forskellige elementer i det virtuelle gruppemøde blev ødelagt (tavler revet ned, larm og råben i mikrofonerne m.m.) på baggrund af deltagernes impulsive førstegangseksperimenteren. I den forbindelse beskæftiger Salmon sig også med en række ting, man skal være klar over, når ny teknologi introduceres, men der kan i sagens natur ikke tages højde for alt. Der sker altid noget uforudset, når ny teknologi tages i anvendelse, og online husreglerne hjælper en hel del ved meget konkret at afstemme en række forventninger til det faglige niveau.

\section{E-tivitet 4 - Vores wiki}

Ressourcen er wikimodulet til "Digital kommunikation på arbejde" via elearn.sdu.dk. Formålet er at skabe en samling af brugbare refleksioner om emnet digital kommunikation i en organisatorisk kontekst. Wikien er inddelt i 8 temaer, baseret på bloggens indhold (e-tivitet 2). Den studerende vælger selv det tema, som han/hun helst vil bidrage til. Her skriver han/hun ét eller flere afsnit med sit indhold. Det er et krav, at den studerende skal koble sine tanker til mindst et af de gennemgående teoretiske begreber fra faget. Det er vigtigt, at den studerende forholder sig til wiki-formen og ikke skriver løs som i en dagbog eller som i Vores cafe (e-tivitet 1). Den studerende opfordres til at holde sin information kort og præcis med en angivelse som minimum af: Hvad er det interessante i forhold til det overordnede tema? Hvilket teoretisk begreb fra vores fag kobler du dine refleksioner til? Derudover skal den studerende vælge mindst et af sine medstuderendes wiki-bidrag og bygge videre på det. Der arbejdes eksplicit med angsten for at redigere i medstuderendes indlæg, som er en af spillereglerne for en wiki. Hele pointen med en wiki er jo, at man ikke kan se den enkelte skribents identitet (men udelukkende dennes produkt), hvilket opleves grænseoverskridende af de fleste studerende. Tanker som "hvem vil dog tillade sig at ødelægge mit gode indlæg?" og "bliver mine medstuderende mon sure over, at jeg redigerer i dette fremmede indlæg?" melder sig ganske hurtigt. I løbet af processen bliver nogle af disse tanker heldigvis vendt til udsagn som "mange tak, fordi du var med til at forbedre mit gode indlæg" og "dejligt, at mine medstude- 
rende kan se, at vi sammen kan gøre dette fremmede indlæg bedre". Etiviteten løber henover en periode på 3 uger, og den studerende skal bidrage med sit eget indlæg inden for den første uge. Som beskrevet leverede bloggen (e-tivitet 2 ) de 8 temaer:

1) Online-offline liv

2) Filtrering og overvågning

3) Online-aktivitet på arbejdspladsen

4) Blogs

5) Online-løsninger og miljø

6) Kundeservice og digitalisering

7) Digitale generationskløfter?

8) E-mail og sms

I kandidatspecialet "Skriv en wiki. Et casestudie af kollaborative skriveprocesser i netbaseret undervisning" undersøger Line Hedeman Nielsen fra IT-Universitetet, hvorledes den asynkrone, kollaborative skriveproces forløber. Efter at have fulgt netop de studerende og særligt deres arbejde med "Vores wiki" (e-tivitet 4) på faget "Digital kommunikation på arbejde", efteråret 2010, påviser Hedeman Nielsen, at den kollaborative skriveproces indeholder i alt 7 faser (mødet, research, teksten skrives, teksten sættes ind, revision, forskønnelse og feedback), og at den kollaborative skriveproces forløber omvendt proportionalt af, hvordan en kooperativ skriveproces typisk forløber. I takt med at wikiindlæggene bliver udarbejdet og redigeret, opløses gruppen/producenten i anonymitet. Hedeman Nielsen konkluderer endvidere, at" [d]en kollaborative skrivning kan resultere i produktion af viden hos de involverede skribenter", ligesom hun peger på, at "[d]en kollaborative skriveproces, der sker i forbindelse med et netbaseret undervisningsforløb har behov for styring og ledelse fra en underviser gennem hele forløbet (...)" (Hedeman Nielsen, 2011, s. 88).

E-tivitet 4 implicerer særligt trin 4 og 5 i Salmons model. De studerende får via e-tiviteterne ydermere mulighed for at udvise kreativitet - ikke blot $\mathrm{i}$ form af "little-c" dækkende den dagligdags kreativitet, som så godt som alle mennesker indeholder, men også for at udvise kreativitet i form af "mini-c" hvor kreativitet indgår i en læringsproces. Mini-c defineres her som "the novel and personally meaningful interpretation of experiences, actions, and events" (Kaufman \& Beghetto, 2009, s. 1). Centralt i Kaufman \& Beghettos definition af mini-c er netop den dynamiske fortolkningsproces, hvor personlig viden og forståelse konstrueres i en specifik sociokulturel kontekst.

Sammenfattende skal det fremhæves, at de 4 e-tiviteter har væsentlige fællestræk. De er alle beskrevet på et detaljeret niveau over for de studerende. Informationerne er givet af underviseren både online og offline. Samtidig er der udstukket præcise krav til både den tidsmæssige og den omfangs-/indholdsmæssige dimension. Den detaljerede beskrivelse og de anførte specifikke krav har til hensigt at hjælpe den studerende ved at fungere som en form for stilladsering (scaffolding). Endvidere bygger den enkelte e-tivitet videre på den foregående, både i form og indhold. For den 
studerende skulle dette gerne gøre læringsrammen lettere at indgå i.

Samtidig bliver den studerende kompetencemæssigt klædt på til at øge niveauet og styrken både med hensyn til det faglige og det digitale. Samlet set kan man for dette forløb sige, at Salmons model virker særligt hensigtsmæssig i trin 1-4, da der ikke er tale om decideret udvikling af ny teori eller lignende (trin 5). Når trin 5 alligevel er nævnt i forbindelse med e-tivitet 3 og 4, er det på baggrund af den gensidige nye viden, der udvikles igennem netop disse e-tiviteter. Grundlæggende skal det fremhæves, at etiviteterne på baggrund af ovennævnte må siges at have nytte af at være udarbejdet med støtte i Salmons 5-trins-model, både for de studerende og for underviseren.

\section{Evaluering}

I det følgende afsnit redegøres for evaluering af e-tiviteternes læringspotentiale, dels fra de studerendes perspektiv, dels fra underviserens perspektiv.

Overordnet evaluering af e-tiviteternes læringspotentiale De studerende tilkendegav, at e-tivitet 3 og de virtuelle fremlæggelser var den mest lærerige e-tivitet. Derefter placerede de studerende e-tivitet 4; Vores wiki, som den næstmest lærerige e-tivitet. Ved evalueringen gav en del studerende udtryk for, at e-tivitet 1: Vores Cafe (diskussionsforum) var den, der bedst kunne undværes i forløbet. Nogle studerende havde helt glemt diskussionsforummet (e-tivitet 1), hvilket kan være en af grundene til, at den så godt som overses i evalueringen. Nedenstående (grafik 2) viser de studerendes svar i forbindelse med den læringsmæssige sammenligning af de 4 e-tiviteter.

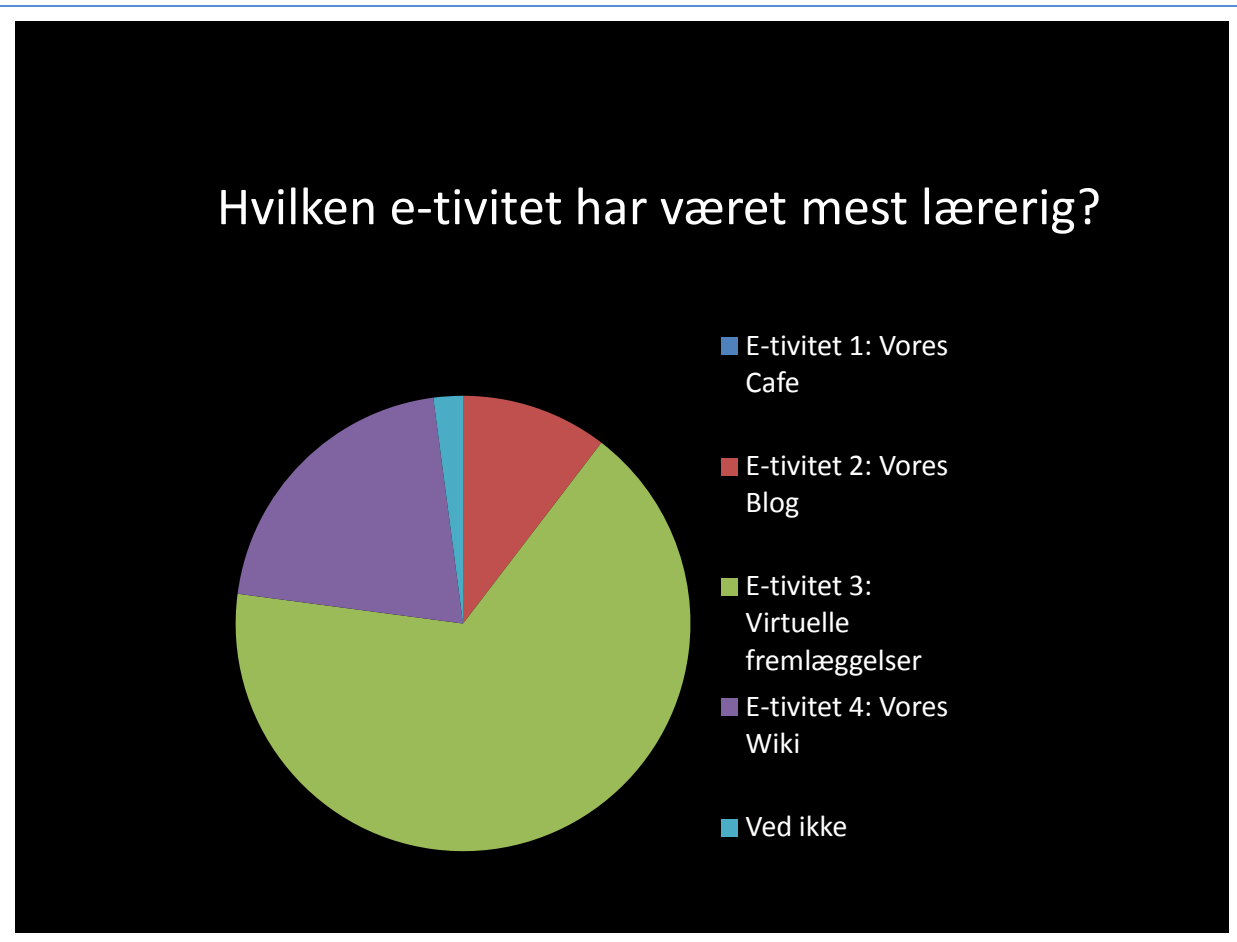

Figur 2. De studerendes overordnede evaluering af e-tiviteterne. 
De studerendes perspektiv

I forbindelse med den overordnede evaluering af e-tiviteterne, fremhæver de studerende især: nye samarbejdsformer, mere seriøst gruppearbejde (online) og øgede digitale kompetencer. Dette afsnit er en sammenskrivning af de studerendes skriftlige midtvejs- og slutevalueringer på faget, efteråret 2010. I alt 65 studerende har besvaret evalueringerne.

Så godt som alle studerende (95\%) mener, at undervisningsformerne i høj grad (60\%) eller i nogen grad (35\%) er passende i forhold til undervisningsmålene. Desuden mener knap to tredjedele af de studerende (72\%), at undervisningen inspirerer dem til at arbejde selvstændigt. 23\% i mindre grad, $5 \%$ slet ikke ( 3 studerende).

I det følgende gengives udvalgte studerendes frie kommentarer, som fremkommer på evalueringsskemaet under teksten: Her kan du uddybe dine svar på spørgsmålene vedrørende undervisningen. Nogle af kommentarerne peger i retning af en initial kritisk holdning til de nye samarbejdsformer. Denne holdning udvikler sig for flere af de studerende undervejs i semestret til en mere positiv holdning, jf. eksempelvis citat B.

Citat A

Jeg har stadig svært ved alt det vi gør online - jeg er lidt dårlig til selvstændigt arbejde.

Citat B

Adobe-øvelsen skræmte mig i starten. Nu synes jeg, at det er sjovt og anderledes at arbejde med.

Nogle af de studerende fremhæver det selvstændige arbejde, inspirationen og lysten til at undersøge yderligere i forbindelse med en e-tivitet, jf. citat C, D og E.

Citat C

Selvstændigt arbejde - ja, jeg føler mig inspireret.

Citat D

Vi beskæftiger os med mange interessante emner, som især gennem bloggen (e-tivity 2) udvides og diskuteres. På bloggen får jeg derfor lyst til at undersøge yderligere om flere emner.

Citat E

God blanding af selvstændigt "e-work", samarbejde og undervisning.

Fleksibiliteten og muligheden for selv at bestemme, hvornår man gør hvad, fremhæves også i evalueringerne, jf. citat F. Mange studerende er særligt 
positive over for det individuelle fleksible arbejde, hvorimod der er mere delte meninger om gruppearbejdet, jf. citat G, H og I. Der er givetvis en generel tendens til delte meninger om gruppe-arbejde både online og offline i forbindelse med undervisning.

\author{
Citat F \\ E-tivities hvor man selv bestemmer hvornår man gør hvad. Super \\ godt. \\ Citat G \\ Det er rigtig godt at afveksle mellem "normal" og online \\ undervisning. Gruppearbejdet kunne jeg dog godt være foruden.
}

\author{
Citat $\mathrm{H}$ \\ Gruppearbejde, online-ikke online. Supervarierende og godt. \\ Godt med "break" fra underviser, hvor man arbejder i grupper.
}

\author{
Citat I \\ Godt med gruppearbejde, hvor vi kan fungere som faglige \\ sparringspartnere for hinanden.
}

I forhold til online gruppearbejdet med tvungen fremlæggelse og optagelse deraf (e-tivitet 3) nævner et par studerende i forbindelse med evalueringen, at de var mindre nervøse ved egen fremlæggelse i forhold til de sædvanlige offline fremlæggelser. Dette går hånd i hånd med Salmons tanker om det væsentlige i at skabe et trygt online-miljø. En gruppe skriver således: "Nemmere/mere afslappende online end i virkeligheden. Man bliver ikke så nervøs online" i en fælles evaluering af e-tivitet 3. Flere af grupperne fremhæver, at de var så optaget af at få gruppearbejdet til at forløbe godt online, at de efterfølgende oplevede det som mere seriøst end offline gruppearbejde. En gruppe skriver: "Vi har oplevet i gruppen, at online-mødet kræver mere koncentration og fuld opmærksomhed, da det er umuligt at aflæse, om alle er med, eller om der er nogen, der sidder med et spørgsmål". Det er svært at sige, om oplevelsen af online gruppearbejdet som mere seriøst og koncentreret samt under mindre nervøsitet udelukkende skyldes online-settingen, eller om det lige så meget skyldes den stramme styring med de udstukne retningslinjer og rollefordelingerne. Måske er det den nye setting og dermed ting fra flere af de nye delelementer, der efterlader dette indtryk hos de studerende.

Teknikken får i evalueringerne mange bemærkninger: "I starten var der problemer med at få alle direkte koblet på, men efter 5 minutter fungerede alt fint" og "Første gang havde vi mange lydudfald, så vi fangede derfor ikke, hvad hinanden sagde og kunne derfor heller ikke spørge og snakke om det. Anden gang var der få udfald, så vi fik alle fremlagt”. Nogle af grupperne valgte at droppe kameraet ved fremlæggelserne. Husreglerne blev overholdt, dog har nogle studerende svært ved at huske at trykke på ikonet med håndsoprækning, inden de tager ordet online. En gruppe skriver: "Vi foretrækker traditionelle møder, da det er nemmere at få sagt alt, uden at tænke på tekniske forstyrrelser". Flere er inde på, at online 
gruppearbejdet er mere tidskrævende end traditionelt gruppearbejde. På baggrund af min undervisningserfaring med både online og offline gruppearbejde vil jeg tillade mig at sætte spørgsmålstegn ved dette, da ny teknologi altid vil opleves som tidskrævende. I det traditionelle offline gruppearbejde er der også et vist tidsspilde (fx transport til mødested, hyggesnak, finde sine sager frem), men det oplever de studerende ikke nær så massivt, fordi de har vænnet sig til denne arbejdsform.

I forbindelse med e-tivity 3 indtog de studerende forskellige roller, mens deres medstuderende fremlagde online. En studerende var ansvarlig for at oprette møderum og for optagelse af mødet, en anden var mødeleder, en tredje tog sig af præsentation af oplægsholder og en fjerde indtog rollen som opponent. Hver rolle var på forhånd detaljeret beskrevet på skrift for de studerende, og tidsmæssigt var der ligeledes klare krav for oplæg og efterfølgende drøftelse. I forhold til indtagelsen af disse forskellige roller er meningerne ganske delte, når de evalueres af de studerende. En gruppe skriver i den forbindelse: "Det fungerede ok med rollerne, dog en smule forvirring mht. hvem, der var hvad. Vi hjalp hinanden", og en anden gruppe skriver: "Nemmere hvis vi hele tiden kun havde samme rolle - lidt forvirrende at skifte." En tredje gruppe skriver: "Fint, nemt at styre og at være de forskellige roller - man gør ligesom i den rigtige verden.", og en fjerde gruppe: "Rollerne var lidt overflødige og uklare, og det var kun oplægsholderen og opponenten, vi opretholdt."

Sammenfattende kan fordele og ulemper ved henholdsvis online og offline gruppearbejde opsummeres som vist i denne model (grafik 3):

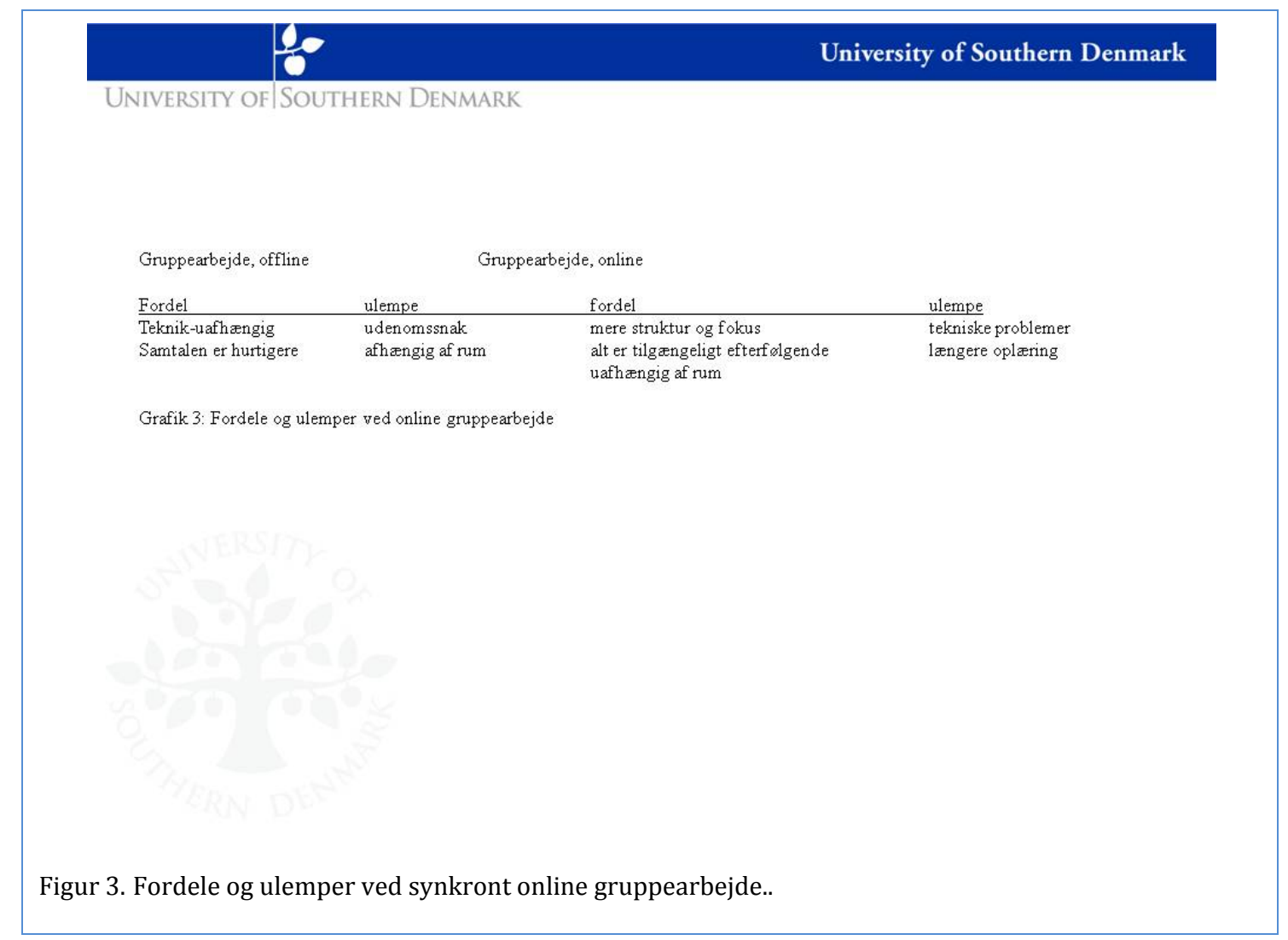


Med hensyn til de øvrige e-tiviteter (e-tivity 1, 2 og 4), som alle er asynkrone, giver uafhængigheden af tid en endnu større fleksibilitet. Uafhængighed af tid kan således føjes til ovennævnte model som en yderligere fordel ved asynkront online-samarbejde.

På spørgsmålet "Hvilken e-tivitet har været mest lærerig?" svarer langt de fleste studerende (67\%), at e-tivitet 3 (Adobe Connect-gruppearbejde) har været mest lærerig. Dernæst kommer e-tivitet 4 (Vores wiki), som $21 \%$ af de studerende finder mest lærerig, e-tivitet 2 (Vores blog), som $10 \%$ af de studerende finder mest lærerig og e-tivitet 1 (Vores cafe) som kun $2 \%$ finder mest lærerig. Nogle af de studerende angiver i evalueringen, at de faktisk helt har glemt e-tivitet 1, hvilket som nævnt kan være en af grundene til, at denne e-tivitet så godt som overses i evalueringen. E-tivitet 1 (Vores cafe - diskussionsforummet) var som beskrevet tænkt som en opvarmningsøvelse i forhold til systemet og tilvænningen til at gå online med sine medstuderende (jf. beskrivelsen af e-tiviteterne).

\section{Underviserens perspektiv}

Som nævnt indledningsvis, kan det hævdes, at det er en skrøne, at alle studerende er gode til digitalt indhold så som at blogge, skrive i en wiki, eksperimentere med lyd og billeder osv. Skrønen bygger bl.a. på Marc Prenskys (2001) udbredte forestilling om modsætningen mellem al ungdom som digitale indfødte (digital natives) versus alle ældre end ungdom som de digitale indvandrere (digital immigrants). De studerende har så godt som alle en Facebook-profil og chatter dagligt, men de er ikke vant til at arbejde professionelt i online-miljøet. For mig at se er der en stor forskel på privatlivets opdateringer og fagligt substantielt online arbejde. Selvom dette kan virke ganske fremmed for de studerende, tager de fleste godt imod eksperimenterne. De virker indstillede på at gøre en indsats for at øge deres digitale kompetencer og kvalificere den faglige diskussion. En gruppe fortsætter i den traditionelle lærer-elev-tænkning og giver udtryk for, at de egentlig hellere ville have pensum serveret fra underviserens side, både på detaljeplan og når det kommer til det store forkromede overblik. En anden gruppe forsøger at krybe udenom e-tiviteterne af mange forskellige grunde (uvant situation, tilbageholdende af natur, generthed, travlhed, dovenskab), men rykker ind og får tingene på plads efter en påtale. Da semestret slutter, dumper 3 af disse studerende, da de ikke har opfyldt kravene til aktiv undervisningsdeltagelse inkl. de obligatoriske e-tiviteter. Enkelte opgiver at følge faget og holder op undervejs inden eksamensterminen. Der er ikke tale om en egentlig repetitionsfase, så på det punkt har e-tiviteterne ikke spillet en rolle for de studerende.

Fra underviserens perspektiv er variationen af medier, settings og modes på en gang udfordrende og berigende. Faget udbydes af medievidenskab, hvor der forskes og undervises i medier fra mange forskellige vinkler. At faget således kan "tage sin egen medicin" og inddrage både tekst, billeder og lyd giver god mening. Samtidig er online- og offline-rammen væsentlig for mange af de faglige diskussioner, der forsøges igangsat netop i faget "Digital kommunikation på arbejde". De studerende skal således i forvejen forholde sig til, hvilken betydning udviklingen inden for denne ramme har 
på flere niveauer, eksempelvis for det enkelte individ, for organisationer og virksomheders liv, samt mere generelt i et samfundsmæssigt perspektiv.

Den ændrede underviserrolle i retning af e-moderator og facilitator er beskrevet mange steder, se fx Buhl (2008). Som underviser bliver det afgørende dels at turde hoppe ud i at arbejde (endnu mere) online sammen med de studerende, dels at være villig til at gøre et forsøg på at ændre sig fra den mere traditionelle underviserrolle i retning af en e-moderator-rolle. Som beskrevet kræver det en stram planlægning og minutiøs forberedelse sammen med en detaljeret eksplicit køreplan for hver e-tivitet. Men det kræver også mod til at eksperimentere online og en god portion humor, når tingene går (lidt) galt. Salmons 5-trins-model kan således langt fra gøre hele arbejdet, men derimod være rammesættende for de enkelte e-tiviteter. Yderligere er det en uvurderlig støtte, at der på uddannelsesinstitutionen er mulighed for support og udviklingsstøtte fra e-læringskonsulenter, så underviseren ikke lades helt alene. Salmon fremhæver desuden, at passion og en dedikeret indsats er påkrævet:

To be successful in designing and running e-tivities you will need
some passion and commitment. At the moment, working online
involves shifting time about and changing patterns of how you
work with colleagues and students. (Salmon, 2002, s. 9).

Indsatsen bliver belønnet med følelsen af at bidrage til den studerendes online læring som supplement til det, der foregår offline. Formålet er, at de studerende flytter sig læringsmæssigt og forsøges motiveret til higher order thinking ved fx i højere og mere synlig grad at blive opfordret til at tage ansvar for egen læring, udføre analyse og indgå i læringsprocessen med kritisk refleksion. Her kan man indvende, at det ikke direkte kan dokumenteres, hvorvidt de studerende fagligt har fået mere hul igennem til pensum, men det er underviserens klare overbevisning, at det faglige niveau er betydeligt højere end året tidligere. Dette kan dokumenteres ved de virtuelle opgaveløsninger og diskussioner, som blev resultatet af etivitet 2-4, ligesom diskussioner og øvelser i offline-situationerne i de øvrige undervisningslektioner også havde et højere fagligt refleksionsniveau. Offline-lektionerne er dog ikke optaget og kan derfor ikke dokumenteres. Der kan naturligvis også være tale om en stærkere årgang end tidligere, hvilket altid er en usikkerhed, også selvom faget afsluttes med en målbar eksamensform fx med karakter (Monty \& Olsen, 2006).

Udover dette kernefaglige aspekt er sidegevinsterne for underviseren også at møde de studerende i forskellige settings og muliggøre, at de studerende kan være produktive, når og hvor de foretrækker (fx midt om natten, derhjemme), hvilket øger det generelle faglige aktivitetsniveau gevaldigt og forberedelsesomfanget imellem lektionerne betragteligt. Samtidig giver et online-offline læringsforløb underviseren adgang til eksplicitte tegn på de studerendes deltagelse, progression og refleksion undervejs i faget - noget som i andre sammenhæng er svært at få adgang til og ofte må opleves alene på baggrund af underviserens mavefornemmelse. Endelig er det altafgørende, at underviseren i dette forløb kan forblive i det professionelle 
område, hvilket ikke ville være muligt, hvis møderammen var valgt i langt mere private regi via online-netværk og programmer som fx Facebook eller Skype.

På det praktiske plan vil jeg som underviser fremhæve, at jeg finder det mere interessant at læse/forholde mig til 72 studerendes forskellige blogog wiki-indlæg, i tematiseret form og med så mange henvisninger til hinanden som muligt, frem for som vanligt at skulle læse/rette de sædvanlige 72 mindre skriftlige opgaver fx à 4 siders længde. Inden etiviteternes indførsel, indgik to mindre skriftlige opgaver i faget som en del af det obligatoriske afleveringsmateriale. Nu bruges tiden på at læse de studerendes online indlæg, på at kommentere og udarbejde opsamlinger, hvilket opleves langt mere varieret og motiverende for underviseren. Samtidig opleves muligheden for direkte feedback fra underviser til den enkelte studerende nemmere end i et traditionelt forløb.

Sammenfattende vil jeg pege på, at de studerende tager godt imod de forskellige eksperimenter, herunder de 4 e-tiviteter og de 3 online undervisningsgange. En stor gruppe af de studerende virker skeptiske, men mange af dem overbevises om hensigts-mæssigheden undervejs, som arbejdet skrider frem. At ændre eksamensformen til e-tiviteter kræver dog meget benarbejde og især klar instruktion fra underviserens side, både mundtligt og skriftligt - og tingene skal gentages mange gange, når man afprøver nye øvelses-, møde- og eksamensformer. Min vurdering er, at det er besværet værd, da det skaber et nyt fagligt sammenhold mellem studerende og underviser og ikke mindst mellem de medstuderende. Enkelte studerende opfatter dog stadig underviseren som serviceperson og mener, at underviseren skal servere overblikket og allerhelst gennemgå pensum side for side, således at de studerende kan læne sig tilbage og blive underholdt. Min vurdering er, at det desværre ikke er alle studerende, der er klar til at arbejde selvstændigt på denne trinstrukturerede måde, hvilket udmønter sig $\mathrm{i}$, at disse studerende, en lille gruppe, må dumpe faget eller holde op undervejs. Andre studerende i denne gruppe udvikler sig undervejs i forløbet og tager mere og mere ansvar.

I forhold til Salmons 5-trins-model vil der fremadrettet kunne arbejdes endnu mere målrettet med denne i forhold til faget og e-tivitetsforløbet. Emoderatorens øgede erfaring med de enkelte e-tiviteter og med trinforløbet vil også her have en betydning. Det vanskeligste i forløbet med etiviteter er - ikke uventet - det uforudsete. Når eksempelvis systemet bryder sammen, computeren går ned, lyden svigter i online mødet eller lignende, kræver det, at underviseren bevarer roen og ikke går i panik. Sammenlignet med en offline situation er vi trods alt nået dertil, hvor lyset i loftet og teknikken i lokalet som hovedregel virker uge for uge. Dette er ikke altid tilfældet for online undervisningsfaciliteterne. Selvom 5-trinsmodellen sikrer en stigende erfaringsmængde og tilvænning, kan online gruppefremlæggelser (e-tivity 3) ikke gennemføres, hvis der opstår tekniske vanskeligheder i forhold til systemet og/eller den enkeltes deltagers udstyr. Når det er sagt, skal det understreges, at det er forsvindende få problemer af den art, jeg har stået med som underviser i dette forløb. 
Konkluderende kan jeg med sikkerhed sige, at obligatoriske e-tiviteter og e-tiviteter som (del af et fags) eksamensform skaber en ramme for at øge de studerendes forberedelses- og generelle faglige aktivitetsniveau mellem lektionerne. Dette giver sig udslag i nogle langt mere fagligt kvalificerede diskussioner undervejs i semesteret, både når vi mødes online og offline. Underviseren har nu mulighed for at dokumentere hele processen, al online indholdet og for at følge aktivitetsniveauet via de specifikke etiviteter. Samtidig har de studerende med denne løsning en formaliseret vej til videndeling med deres medstuderende - en ofte overset mulighed, som ikke nødvendigvis opstår spontant eller formås faciliteret i traditionel offline undervisning.

\section{Referencer}

Biggs, John \& Tang, Catherine (2009) Teaching for Quality Learning at University. Berkshire: McGraw-Hill.

Buhl, Mie (2008) New Teacher functions in cyberspace - on technology, mass media and education. I: Seminar.net. Media, technology and life. www.seminar.net

Dohn, Nina Bonderup \& Johnsen, Lars (2009) E-læring på web 2.0. Frederiksberg: Samfundslitteratur.

Jacques, David \& Salmon, Gilly (2007) Learning in Groups. A handbook for face-to-face and online environments. London: Routledge.

Kaufman, James C. \& Beghetto, Ronald A (2009) Beyond Big and Little: The Four C Model of Creativity. Review of General Psychology. Vol 13, No. 1, 1-12.

Monty, Anita \& Olsen, Carsten Smith (2006) Hvordan bliver studerende aktive i fjernundervisning? Brug af en trinvis, struktureret model til fremme af interaktion og læring. Tidsskrift for universiteternes efter- og videreuddannelse. Nr. 8.

Nielsen, Line Hedeman (2011) Skriv en wiki. Et casestudie af kollaborative skriveprocesser i netbaseret undervisning. Kandidatspeciale. Digital Design og Kommunikation. IT-Universitetet i København.

Prensky, Marc (2001) Digital Natives, Digital Immigrants. On the Horizon. MCB University Press. Vol. 9. No. 5.

Salmon, Gilly (2002) E-tivities. The key to active online learning. London: Routledge Falmer.

Slevin, James (2006) E-tivities and the connecting of e-learning experiences through deliberative feedback. Tidsskrift for universiteternes efter- og videreuddannelse. Nr. 9. 